\title{
Low temperature circulating fluidized bed gasification and co-gasification of municipal sewage sludge. Part 2: Evaluation of ash materials as phosphorus fertilizer
}

Thomsen, Tobias Pape; Hauggaard-Nielsen, Henrik; Gøbel, Benny; Stoholm, Peder; Ahrenfeldt, Jesper; Henriksen, Ulrik Birk; Müller-Stöver, Dorette Sophie

Published in:

Waste Management

Link to article, DOI:

10.1016/j.wasman.2017.04.043

Publication date:

2017

Document Version

Peer reviewed version

Link back to DTU Orbit

Citation $(A P A)$ :

Thomsen, T. P., Hauggaard-Nielsen, H., Gøbel, B., Stoholm, P., Ahrenfeldt, J., Henriksen, U. B., \& MüllerStöver, D. S. (2017). Low temperature circulating fluidized bed gasification and co-gasification of municipal sewage sludge. Part 2: Evaluation of ash materials as phosphorus fertilizer. Waste Management, 66, 145-154. https://doi.org/10.1016/j.wasman.2017.04.043

\section{General rights}

Copyright and moral rights for the publications made accessible in the public portal are retained by the authors and/or other copyright owners and it is a condition of accessing publications that users recognise and abide by the legal requirements associated with these rights.

- Users may download and print one copy of any publication from the public portal for the purpose of private study or research.

- You may not further distribute the material or use it for any profit-making activity or commercial gain

- You may freely distribute the URL identifying the publication in the public portal 
1 Low Temperature Circulating Fluidized Bed gasification and co-gasification of

2 Municipal Sewage Sludge. Part 2: Evaluation of ash materials as phosphorus fertilizer

3

4

5

6

7

8

9

10

11

12

13

14

15

Tobias Pape Thomsen ${ }^{a}$, Henrik Hauggaard-Nielsen ${ }^{b}$, Benny Gøbel ${ }^{c}$, Peder Stoholm ${ }^{d}$, Jesper Ahrenfeldt ${ }^{a}$, Ulrik Henriksen ${ }^{a}$, Dorette Sophie Müller-Stöver ${ }^{e}$

${ }^{a}$ Technical University of Denmark, Department of Chemical Engineering, DTU Risø Campus, Technical University of Denmark Building 313,

Frederiksborgvej 399, 4000 Roskilde, Denmark

${ }^{b}$ Roskilde University, Department of Environmental, Social and Spatial Change, 4000 Roskilde, Denmark

${ }^{c}$ DONG Energy Thermal Power A/S, Nesa Allé 1, 2820 Gentofte, Denmark

${ }^{d}$ Danish Fluid Bed Technology ApS, Industrivej 38, 4000 Roskilde, Denmark

${ }^{e}$ University of Copenhagen, Department of Plant and Environmental Sciences, Plant and Soil Science, Thorvaldsensvej 40, Frederiksberg, Denmark

\begin{abstract}
The study is part 2 of 2 in an investigation of gasification and co-gasification of municipal sewage sludge in low temperature gasifiers. In this work, solid residuals from thermal gasification and co-gasification of municipal sewage sludge were investigated for their potential use as fertilizer. Ashes from five different Low Temperature Circulating Fluidized Bed (LT-CFB) gasification campaigns including two mono-sludge campaigns, two sludge/straw mixed fuels campaigns and a straw reference campaign were compared. Experiments were conducted on two different LT-CFBs with thermal capacities of $100 \mathrm{~kW}$ and $6 \mathrm{MW}$, respectively. The assessment included: i) Elemental composition and recovery of key elements and heavy metals; ii) content of total carbon (C) and total nitrogen (N); iii) pH; iv) water extractability of phosphorus after incubation in soil; and v) plant phosphorus response measured in a pot experiment with the most promising ash material. The results showed that co-gasification of straw and sludge in LT-CFB gasifiers gave the best fertilizer qualities across all assessed characteristics. These mixed fuel gasification ashes had a high content of recalcitrant $\mathrm{C}$, phosphorus (P) and potassium (K), a low content of heavy metals (especially cadmium) and an improved plant $\mathrm{P}$ availability compared to the mono-sludge ashes. It was also found that bottom ashes from the char reactor contained even less heavy metals than cyclone ashes. It is concluded that LT-CFB gasification and co-gasification is a highly effective way to purify and sanitize sewage sludge for subsequent use in agricultural systems.
\end{abstract}

Keywords: Municipal sewage sludge; cereal straw; thermal gasification; phosphorus fertilizer ash; heavy metals

\title{
1 Introduction
}

Phosphorus $(P)$ is an essential macro nutrient and the availability of $P$ in agricultural systems is often a limiting factor especially in older soils as the ones found in mid and lower Africa, Asia and Australia [1-4]. The main source for $\mathrm{P}$ fertilizer, mined phosphate rock, is a critical non-renewable globally demanded resource and there is an increasing concern about the commercial availability of this resource in the near future (Cordell and White, 2014). Determinations of the $P$ depletion rate and especially quantifications of the remaining $P$ resource have been the subject of a recent scientific debate (Edixhoven et al., 2013; Scholz and Wellmer, 2016, 2013), but it is generally agreed on that the geopolitical importance of the $P$ resource is increasing as is the urgency of developing more efficient P management strategies (Chowdhury et al., 2016; Ott and Rechberger, 2012). 
A substantial proportion of $\mathrm{P}$ used in agriculture ends up in municipal sewage sludge (MSS) (Kahiluoto et al., 2015), and recycling this fraction via direct application of MSS to agricultural soil has been considered a cheap and efficient way to enhance and fertilize soils (Chowdhury et al., 2016; Fytili and Zabaniotou, 2008; Linderholm et al., 2012). However, the extent of direct MSS soil application varies greatly among countries and regions, and the variation is caused by many different factors including practical alternatives, differences in sludge quality as well as political and cultural restrictions (Fytili and Zabaniotou, 2008; Hukari et al., 2016; Kelessidis and Stasinakis, 2012). In recent years, there has been a growing concern in many countries of the potential risks associated with the content of emerging organic pollutants and xenobiotics in MSS, including antibiotics, fragrances, UV-filters, antiseptics, micro plastics, phthalates, hormones and much more (Choban and Winkler, 2008; Igos et al., 2012; Krüger et al., 2014; Michael et al., 2013). As a consequence of this growing concern, there is an increasingly restrictive political attitude towards direct application of sewage sludge in many countries (Krüger and Adam, 2015), and alternative management options are continuously developed and implemented. Thermal gasification of sludge is one of these alternatives (Qian and Jiang, 2014).

All types of thermal conversion of municipal sewage sludge leads to production of one or more ash-and/or char fractions. The quality and quantity of these products can vary substantially with the quality of the parent sludge and the design of the thermal process (Fericelli, 2011; Jakobsen and Willett, 1986; Li et al., 2015; Qian and Jiang, 2014). Many scientific studies have been conducted to examine the potential application of incineration ashes and pyrolysis chars in agricultural systems as fertilizers and/or soil enhancers. These studies usually involve investigation of one or several of the following characteristics: Content and type of toxins; fate and mobility of heavy metals; determination of eco-toxicity levels; content and availability of macro- and micro nutrients; technical routes for down-stream upgrading and potential long-term carbon sequestration (Fraser and Lum, 1983; Furr et al., 1980, 1979; Hossain et al., 2015; Jakobsen and Willett, 1986; Liu et al., 2014; Lu et al., 2013; Mellbye et al., 1982; Méndez et al., 2012; Song et al., 2014; Sousa and Figueiredo, 2015). However, to this date, no published studies on the fertilizer quality of ashes and chars from thermal gasification of municipal sewage sludge have been identified. Most studies on thermal gasification of sewage sludge are focused on the potential energy recovery, the technical feasibility of the process and the gas quality (Manara and Zabaniotou, 2012; Seggiani et al., 2012; Zhu et al., 2015).

The aim of this study was to test the use of two Low-Temperature Circulating Fluidized Bed Gasifiers (LT-CFBs) to convert MSS focusing on the quality of the solid process residuals and the potential use of these solid products as fertilizers and/or soil enhancers. Gasification ashes were collected from two MSS campaigns, two MSS/straw co-gasification campaigns and a straw reference campaign. Ash analysis included i) Composition and elemental balances of macro nutrients and heavy metals; ii) pH measurements and iii) incubation studies and pot experiments to determine phosphorus fertilizer quality.

This work is part of a larger assessment of the suitability of the LT-CFB gasification technology as a platform to convert municipal sewage sludge to electricity, heat and ash fertilizer. The complete assessment is composed of the following two parts: 
- Part 1: Assessment of process feasibility and stability, process performance and energy efficiency, product distribution and gas product characteristics (Thomsen et al., 2016)

- Part 2: Characterization of LT-CFB ashes as P fertilizer and determination of key elemental balances (this study)

\section{Materials and Methods}

\subsection{The LT-CFB gasifier}

Two LT-CFB units currently exist; a $100 \mathrm{kWth}$ pilot scale plant at the Technical University of Denmark located at Ris $\varnothing$ near Roskilde, Denmark, and a 6 MWth demonstration unit at DONG Energy's Asnaes Powerplant in Kalundborg, Denmark. Both plants are involved in the present study. The LT-CFB technology is commercially registered as the Pyroneer Gasifier by DONG Energy and has been described previously (Ahrenfeldt et al., 2013; Narayan et al., 2016; Nguyen et al., 2013; Nielsen, 2007; Thomsen et al., 2016, 2015). A generalized process flow chart of the LT-CFB gasifier is provided in Figure 1.

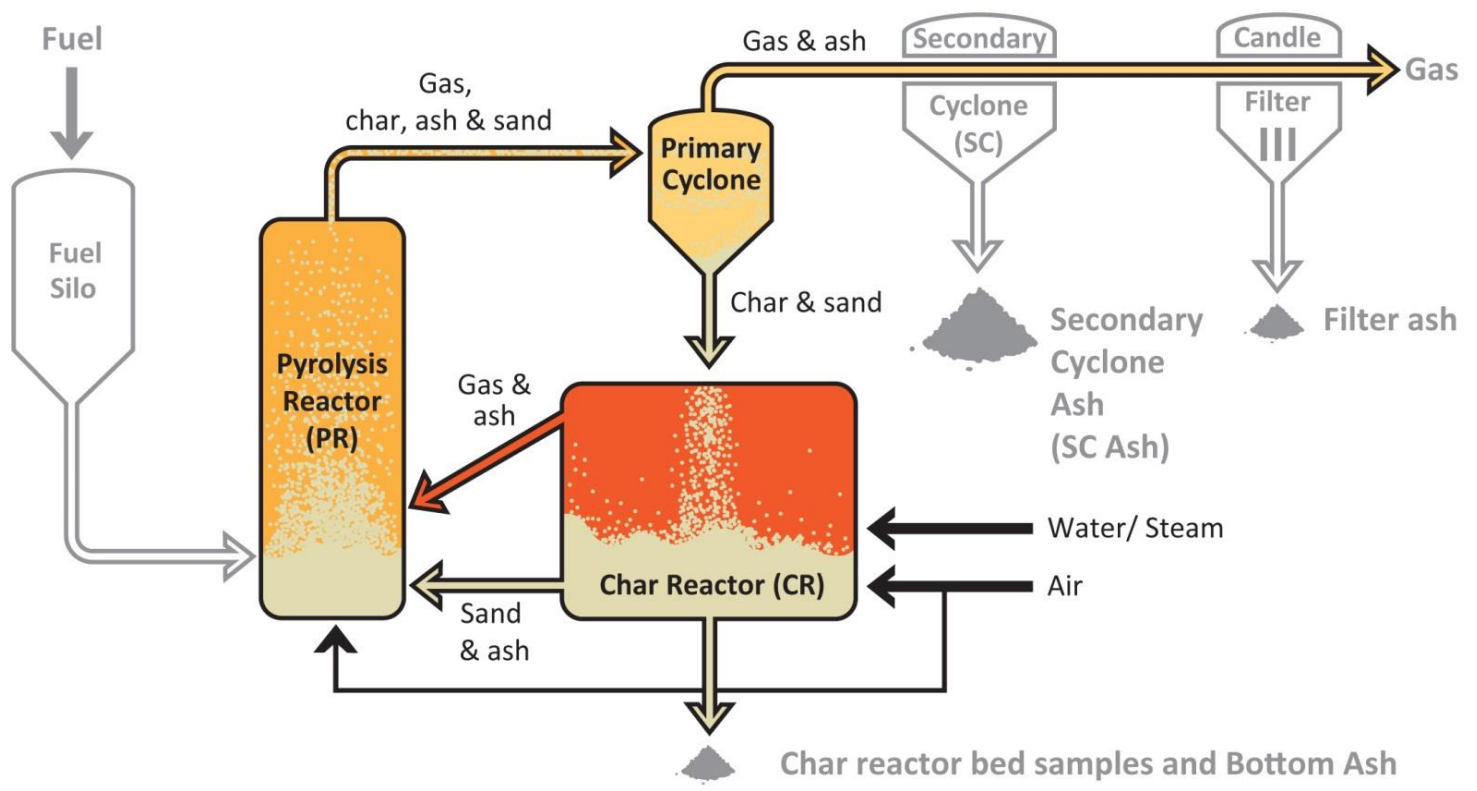

Figure 1: Illustration of a Low Temperature Circulating Fluidized bed (LT-CFB) gasification system with indications of the main input and product streams. Adapted from (Thomsen et al., 2015)

\subsection{The sewage sludge fuels and LT-CFB campaigns}

The applied MSS samples originated from three different Danish wastewater treatment plants (WWTPs) and the samples were collected at different seasons. The three WWTPs that supplied the sludge samples for the study are characterized as follows:

Stegholt WWTP (Aabenraa, Denmark): Constructed as a Mechanical-Biological (active sludge loop)-NitrificationDenitrification-Chemical cleaning facility (MBNDC). However, the use of precipitation chemicals for P capture 


\begin{tabular}{|c|c|c|c|c|}
\hline Campaign description & Abbreviation & Fuel type & $\begin{array}{l}\text { Sludge origin } \\
\text { (WWTP) }\end{array}$ & LT-CFB plant \\
\hline $\begin{array}{l}\text { Reference } \\
\text { campaign }\end{array}$ & REF & $\begin{array}{l}\text { Crushed wheat straw } \\
\text { pellets (Denmark) }\end{array}$ & None & $\begin{array}{l}\text { Ris } \varnothing \text { DTU } \\
\left(100 \mathrm{~kW}_{\text {Th }}\right)\end{array}$ \\
\hline $\begin{array}{l}\text { Mono-gasification of sludge } \\
\text { from Randers }\end{array}$ & SLU-RA & Dry sludge granules & Randers & $\begin{array}{l}\text { Ris } \varnothing \text { DTU } \\
\left(100 \mathrm{~kW}_{\mathrm{Th}}\right)\end{array}$ \\
\hline $\begin{array}{l}\text { Co-gasification of mixed fuel } \\
\text { with sludge from } \underline{\text { Stegholt }}\end{array}$ & MIX-ST & $\begin{array}{l}\text { Mix: Dewatered sludge + } \\
\text { crushed straw pellets }\end{array}$ & Stegholt & $\begin{array}{l}\text { Ris } \varnothing \text { DTU } \\
\left(100 \mathrm{~kW}_{\text {Th }}\right)\end{array}$ \\
\hline $\begin{array}{l}\text { Co-gasification of mixed fuel } \\
\text { with sludge from } \underline{\text { Bjergmarken }}\end{array}$ & MIX-BJ & $\begin{array}{l}\text { Mix: Dry sludge pellets + } \\
\text { crushed straw pellets }\end{array}$ & Bjergmarken & $\begin{array}{c}\text { Asnaes Power plant } \\
\left.\text { (6 } \mathrm{MW}_{\mathrm{Th}}\right)\end{array}$ \\
\hline $\begin{array}{l}\text { Mono-gasification of sludge } \\
\text { from Bjergmarken }\end{array}$ & SLU-BJ & Dry sludge granules & Bjergmarken & $\begin{array}{l}\text { Ris } \varnothing \text { DTU } \\
\left(100 \mathrm{~kW}_{\text {Th }}\right)\end{array}$ \\
\hline
\end{tabular}

has been phased out through constant process optimization. Iron chloride is still applied in the clarifiers to optimize the sedimentation of floating sludge. The MSS is treated by thermophilic anaerobic digestion for up to 18 days at the WWTP before it is dewatered mechanically and exported.

Randers WWTP (Randers, Denmark): A representative Danish MBNDC where P is captured approximately $50 \%$ biologically and $50 \%$ chemically using a mix of iron chloride and aluminum. This estimation is based on the annual use of precipitation chemicals at the time of the LT-CFB experiment and an assumption of a 1:1.8 capturing rate for aluminum and of 1:3 for iron. All sludge goes through the active sludge cycle before it is digested anaerobically in a mesophilic process with a retention time close to one month. The sample for the LTCFB campaign was dried at the WWTP in a Krüger BioCon dryer with temperatures ranging from $100-175^{\circ} \mathrm{C}$.

Bjergmarken WWTP (Roskilde, Denmark): Another representative Danish MBNDC facility where precipitation chemicals are added before the active sludge cycle and phosphorous is captured approximately $70 \%$ biologically and $30 \%$ chemically. Iron chloride sulfate and aluminum chloride is used to capture P and precipitate sludge. All sludge goes through the active sludge cycle before it is digested anaerobically for almost three weeks in a thermophilic digestion process. After digestion, the sludge is mechanically dewatered and dried in a Krüger BioCon dryer (100-175 $\left.{ }^{\circ} \mathrm{C}\right)$. MSS products can be delivered as de-watered sludge, as dry granules or as dry pellets.

The LT-CFB campaigns include a reference campaign on straw (REF campaign), two campaigns on mono sludge fuels (SLU campaigns) and two campaigns with co-gasification of sludge and straw (MIX campaigns). A short description of the campaigns is provided in Table 1. More details and data on fuels and LT-CFB campaigns can be found in part 1 of the study (Thomsen et al., 2016). The fuels applied in the MIX-ST and MIX-BJ experiments have been designed to provide ashes with P:K relationships around 1:2.

Table 1: Overview of Low Temperature Circulating Fluid Bed (LT-CFB) sludge gasification campaigns. WWTP: Wastewater treatment plant. Th: Thermal capacity. 
118 Proximate analysis of fuels samples (Thomsen et al., 2016) have shown substantial differences among the 119 different fuels with regard to moisture content (5-30 wt\% as received) and ash content (8-43 wt\% dry basis) whereas the content of volatile organics (43-69 wt\% dry basis) and recalcitrant carbon (14-24 wt\% dry basis) as well as the higher heating value (11-16 $\mathrm{MJ} / \mathrm{kg}$ as received) were more comparable.

Ash samples have been collected from the secondary cyclones (SC, Figure 1) in all campaigns. In addition to the SC ashes, a filter ash sample from the SLU-BJ candle filter as well as a final composition char reactor (CR) bed sample from the MIX-ST and SLU-BJ campaigns and a size separated sand-free char reactor bottom ash sample from the SLU-BJ campaign were collected. 2-5 kg of each ash sample was collected.

\subsection{Analytical procedures}

Ash samples were examined on dry basis for their content of volatile material, recalcitrant carbon and ash using standards ASTM D3174-73, DS/EN 14775 (2009) and EN 15169 (2007).

Higher Heating values were measured by a calorimetric method using a Parr 6300 Bomb Calorimeter and DS/EN 14918 (2010).

The inorganic compositions of fuels, chars and ashes from REF, MIX-ST and MIX-BJ campaigns were determined by an external laboratory, FORCE Laboratory, using a combination of DS/EN ISO 11885 (2009), DS/EN 15290 (2011), inductively coupled plasma optical emission spectrometry (ICP-OES) and inductively coupled plasma mass spectrometry (ICP-MS). Cl was determined using DS/EN 15289 (2011) while Hg was determined using EPA 7473 (2007). Samples from the SLU-RA campaign was analyzed at the external laboratory at Kommunekemi A/S using standard DS259 for preparation and digestion of the samples and ICP-MS by the DS/EB ISO 17294-1-2 standard for the subsequent analysis. Samples from SLU-BJ have been analyzed by ICP-OES (Optima 5300 DV, Perkin Elmer, USA) using the procedure described by Hansen et al. (2009) (Hansen et al., 2009) after digestion with $\mathrm{HNO}_{3}, \mathrm{H}_{2} \mathrm{O}_{2}$ and $\mathrm{HF}$.

Total $\mathrm{C}$ and $\mathrm{N}$ content was measured at the Center for Permafrost of the Department of Geosciences and Natural Resource Management, University of Copenhagen, by Dumas combustion (1020 드) on an elemental analyser (CE 1110, Thermo Electron, Milan, Italy).

The $\mathrm{pH}$ was determined by mixing $1 \mathrm{~g}$ of dry, grinded ash or sludge with $25 \mathrm{ml}$ of milliQ water before shaking ( 1 hour), settling of suspended particles and measurement on a pH meter (Mettler-Toledo AG, Switzerland).

Elemental balances have been conducted based on the product distribution determined in part 1 of the study (Thomsen et al., 2016) combined with the fuel and ash compositions.

\subsection{Determination of plant available $P$ in ash}

Assessment of $\mathrm{P}$ fertilizer quality of the ashes was conducted in two experiments: i) a short-term soil incubation study screening sludge and ash samples from all campaigns with subsequent assessment of water extractable P; ii) a plant pot experiment measuring barley aboveground biomass production and $\mathrm{P}$ uptake with 
SC ashes from the MIX-ST campaign as P fertilizer. The soil selected for the study was taken from the upper layer of an agricultural field at DTU, Roskilde Campus $\left(55^{\circ} 41^{\prime} \mathrm{N}, 12^{\circ} 05^{\prime} \mathrm{E}\right)$ and contained $10 \%$ clay, $12 \%$ silt, $46 \%$ fine sand and $30 \%$ coarse sand. The soil was air-dried and sieved to obtain the fraction $\leq 2 \mathrm{~mm}$ for the incubation study and $\leq 1 \mathrm{~cm}$ for the pot experiment. The soil had a total carbon (C) content of $12 \mathrm{~g} \mathrm{~kg}^{-1}$, a total nitrogen $(\mathrm{N})$ content of $1.1 \mathrm{~g} \mathrm{~kg}^{-1}$, a bicarbonate-extractable phosphorus (Olsen-P) content of $6 \mathrm{mg} \mathrm{kg}^{-1}$, an extractable $\mathrm{K}$ content of $69 \mathrm{mg} \mathrm{kg}^{-1}$ and a $\mathrm{pH}$ of 5.9 (water).

\subsubsection{Soil incubation study:}

All MSS and ash samples were ground in a Mahlkönig Kenia Disc grinder (MAHLKÖNIG GmbH \& Co. KG, Hamburg, Germany) and particles larger than $0.125 \mathrm{~mm}$ were extracted by sieving on a Retsch Vibro Sieve (Retsch GmbH, Haan, Germany) and subsequently crushed in a FRITSCH Mortar Grinder Pulverisette 2 (Fritsch $\mathrm{GmbH}$, Idar-Oberstein, Germany). Sieving and crushing of the large particle fraction was repeated until at least $90 \%$ of the total sample mass passed a $0.125 \mathrm{~mm}$ sieve and all particles were smaller than $0.25 \mathrm{~mm}$. Final particle size distribution of the samples was determined using sieves $25 \mu \mathrm{m}, 75 \mu \mathrm{m}, 125 \mu \mathrm{m}$ and $250 \mu \mathrm{m}$.

Triplicates of $50 \mathrm{~g}$ soil/quartz sand mixture $(50: 50 \mathrm{w} / \mathrm{w})$ were mixed with ash samples at a rate of $80 \mathrm{mg} \mathrm{P} \mathrm{kg}^{-1}$ soil by thorough shaking and watered with demineralized water to $50 \%$ of the soil's water holding capacity. Mass fraction of sludge and ashes in the mixtures were: Mono-sludge ashes (SLU) $=0.1 \%$, Dry sludge (SLU \& $\mathrm{MIX})=0.2 \%$, Mix ashes $(\mathrm{MIX})=0.3 \%$ and straw ash $(\mathrm{REF})=2 \%$. Substrate-free controls and mineral $\mathrm{P}\left(\mathrm{KH}_{2} \mathrm{PO}_{4}\right)$ dosed reference samples were included. Samples were incubated in a climate chamber at $85 \% \mathrm{RH}$ and $20^{\circ} \mathrm{C}$ for 1 week. After incubation, $0.75 \mathrm{~g}$ sample (dry basis) was shaken with $45 \mathrm{ml}$ of purified water for 1 hour in a 50-ml Falcon tube, centrifuged ( $1 \mathrm{~min}, 3500 \mathrm{rpm}$ ), and the supernatant was filtered through a Whatman no. 5 filter paper. Extracts were stored at $4^{\circ} \mathrm{C}$ before analysis of water extractable P on a Flow Injection Analyzer (FIAstart 5000, FOSS, Denmark).

\subsubsection{Plant pot experiment}

For the pot experiment, the MIX-ST ash material was incorporated into a mixture of soil and quartz sand (50:50 $\mathrm{w} / \mathrm{w}$ ) at a rate of $0,40,60,80$, and $100 \mathrm{mg}$ total $\mathrm{P} / \mathrm{kg}$ dry soil with 4 replicates per treatment. Pots (2.5 kg soil substrate) receiving mineral P-fertilizer $\left(\mathrm{KH}_{2} \mathrm{PO}_{4}\right)$ or straw gasification ash from the REF campaign at the same total $\mathrm{P}$ rates were set up as positive controls. A negative control not receiving any $\mathrm{P}$ fertilizer was also included. $\mathrm{K}_{2} \mathrm{SO}_{4}$ was added to all treatments except the REF treatment and the MIX-ST treatment at the highest $\mathrm{P}$ rate to give a final concentration of $200 \mathrm{mg} \mathrm{K} \mathrm{kg}^{-1}$ dry soil. $\mathrm{CaCl}_{2} \times 2 \mathrm{H}_{2} \mathrm{O}\left(20 \mathrm{mg} \mathrm{Ca} \mathrm{kg}^{-1}\right.$ soil), $\mathrm{MgSO}_{4} \times 7 \mathrm{H}_{2} \mathrm{O}\left(9 \mathrm{mg} \mathrm{Mg} \mathrm{kg}^{-1}\right.$ soil), $\mathrm{NH}_{4} \mathrm{NO}_{3}$ (50 mg N kg soil) and micronutrients ( $3 \mathrm{mg} \mathrm{Mn}, 1.2 \mathrm{mg} \mathrm{Zn,} 0.5 \mathrm{mg} \mathrm{Cu}$, and $0.07 \mathrm{mg} \mathrm{Mo} \mathrm{kg}^{-1}$ soil, respectively) were further added to each pot. During the course of the experiment, all pots received another 9 $\mathrm{mg} \mathrm{Mg} \mathrm{kg}{ }^{-1}$ soil and $175 \mathrm{mg} \mathrm{N} \mathrm{kg}^{-1}$ soil. Pots were randomized and placed in a growth chamber with a $16 \mathrm{~h} \mathrm{day}^{-1}$ photoperiod and an average temperature of $24 / 16{ }^{\circ} \mathrm{C}$ (day/night). Six seeds of spring barley (cv. Iron) were sown into each pot, which were thinned to three plants after emergence. Pots were regularly watered to maintain soil moisture at ca. $60 \%$ of the soil's water holding capacity. The aboveground biomass of barley plants was harvested after 7 weeks of plant growth, dried in an oven at $70^{\circ} \mathrm{C}$ for $48 \mathrm{~h}$ and weighed. The dry plant material was finely ground and a subsample was wet-digested in a solution of nitric and perchloric acid 
$(4: 1, v / v)$. Total P concentration in the digest was measured on an AutoAnalyzer 3 (Bran+Luebbe, Norderstedt, 189 Germany).

190 Statistical analyses were carried out using STATISTICA software (Statsoft Inc. 2010). All tests of significance 191 were conducted at $\mathrm{P} \leq 0.05$. When data were not normally distributed or showed heterogeneity of variances, 192 they were log-transformed before analysis. Data was analyzed with a one-way ANOVA and when significant F193 tests were obtained, multiple mean comparisons were carried out using Tukey's Honest Significant Difference 194 (HSD) test.

\section{Results and discussion}

\subsection{Proximate analysis of ash samples}

198 Results from the proximate analysis of the ash samples showed much lower ash content in the MIX and REF SC 199 ashes than in the SLU ashes (Table 2).

Table 2: Proximate analysis of dry ash samples. DM: Dry matter. SC: Secondary cyclone. CR: Char reactor.

\begin{tabular}{ccccc}
\hline Campaign & Ash sample & $\begin{array}{c}\text { Volatiles } \\
\% \text { DM }\end{array}$ & $\begin{array}{c}\text { Recalcitrant carbon } \\
\% \text { DM }\end{array}$ & $\begin{array}{c}\text { Ash } \\
\% \text { DM }\end{array}$ \\
\hline SLU-BJ & SC ash & $1.4 \pm 0.3$ & $3.0 \pm 0.2$ & $95.7 \pm 0.2$ \\
SLU-RA & SC ash & $1.1 \pm 0.3$ & $4.3 \pm 0.9$ & $94.6 \pm 0.9$ \\
MIX-ST & SC ash & $8.9 \pm 0.1$ & $27.6 \pm 1.3$ & $63.5 \pm 1.3$ \\
MIX-BJ & SC ash & $5.0 \pm 0.2$ & $22.0^{*}$ & $73.0^{*}$ \\
REF & SC ash & $6.3 \pm 0.3$ & $36.7^{*}$ & $57.0^{*}$ \\
SLU-BJ & Filter ash & $1.6 \pm 0.2$ & $3.5 \pm 0.1$ & $94.9 \pm 0.1$ \\
SLU-BJ & CR bottom ash & $1.8 \pm 0.1$ & $2.6 \pm 0.2$ & $95.6 \pm 0.2$ \\
\hline
\end{tabular}

201

Likewise, the content of volatile organic material was a factor of 4-8 higher in the MIX and REF SC ashes than in the SLU ashes while the content of recalcitrant carbon was a factor of 5-12 higher. Despite the differences in the total quantity, the ratio between the volatile and recalcitrant carbon was found to be relatively stable (0.20.5 ) among all SC ashes. Applying data on the proximate composition of the fuels as well as product distribution from part 1 (Thomsen et al., 2016) it is estimated that the degree of conversion of volatile organics was around $99 \%$ in all campaigns, and that the degree of conversion of recalcitrant carbon varied between $82-$ $86 \%$ in the MIX and REF campaigns and $94-95 \%$ in the SLU campaigns. The data cannot be used to suggest, which materials will provide the most recalcitrant carbon for soil sequestration, but there will be a much larger potential pool of recalcitrant carbon as well as volatile organics in the ashes from co-gasification than in the ashes from MSS gasification alone. 


\subsection{Elemental analysis and elemental mass balance}

214 Most of the $\mathrm{N}$ originally present in the fuel was transferred to the gas phase while the $\mathrm{C}$ content in the ashes 215 varied substantially with the type of fuel (Table 3).

Table 3: C and N content of fuels and ashes. DM: Dry matter. SC: Secondary cyclone. CR: Char reactor.

\begin{tabular}{cccc}
\hline Campaign & Sample & $\begin{array}{c}\text { Total C } \\
\% \mathrm{DM}\end{array}$ & $\begin{array}{c}\text { Total N } \\
\% \mathrm{DM}\end{array}$ \\
\hline SLU-BJ & Sludge & $27.6 \pm 0.1$ & $3.9 \pm 0.0$ \\
SLU-RA & Sludge & $28.7 \pm 0.4$ & $3.9 \pm 0.1$ \\
MIX-ST & Sludge & $30.6 \pm 0.1$ & $4.4 \pm 0.0$ \\
MIX-BJ & Sludge & $27.6 \pm 0.1$ & $3.8 \pm 0.0$ \\
SLU-BJ & SC ash & $4.2 \pm 0.0$ & $0.4 \pm 0.0$ \\
SLU-RA & SC ash & $6.7 \pm 0.1$ & $0.4 \pm 0.0$ \\
MIX-ST & SC ash & $25.5 \pm 0.0$ & $0.7 \pm 0.0$ \\
MIX-BJ & SC ash & $23.8 \pm 0.2$ & $0.4 \pm 0.0$ \\
REF & SC ash & $44.5 \pm 0.3$ & $0.4 \pm 0.0$ \\
SLU-BJ & Filter ash & $5.2 \pm 0.0$ & $0.4 \pm 0.0$ \\
SLU-BJ & CR ash & $7.1 \pm 0.1$ & $0.4 \pm 0.0$ \\
\hline
\end{tabular}

217

Combining data from Table 3 and the ash production rates from the different campaigns (Thomsen et al., 2016), it is determined that in mono-sludge campaigns 1-2 \% of the fuel $\mathrm{N}$ is recovered in the SC ash and 0-1\% is captured in the Filter ash. In the reference campaign and the two mix campaigns, $4-5 \%$ of the fuel $\mathrm{N}$ is recovered in the SC ashes. From an $\mathrm{N}$-conservation point of view, it seems like there is an advantage from cogasification in this regard, especially since the $\mathrm{N}$ concentration in dry sludge fuels can be expected to be at least 4-5 times as high as in dry mix and straw fuels (ECN, 2016a, 2016b). However, plant availability of $\mathrm{N}$ in sewage sludge biochar is reported to be substantially lower than in the feedstock, decreasing with increasing conversion temperature (Wang et al., 2012).

LT-CFB ashes produced from straw have previously been found to be highly suitable for carbon sequestration and provide other soil benefits as well (Hansen et al., 2015). However, the very low carbon content in the mono-sludge SC ashes decreases the potential effect of using these ashes to sequester carbon and increase the content of organic carbon in soils, and could also affect other common biochar characteristics like high cation exchange capacity, water retention etc. In this regard co-gasification of MSS and straw is also found to have an advantage compared to mono-gasification of MSS. Char from MSS pyrolysis as well as ashes from straw gasification has recently been shown to increase these soil fertility parameters significantly, but no studies on the effect of ashes from MSS gasification or co-gasification have been found (Hansen et al., 2016; Sousa and Figueiredo, 2015).

When ash is considered as a fertilizer, the content of major nutrients $\mathrm{P}$ and $\mathrm{K}$ is especially interesting. 
The $\mathrm{P}$ content in sludge is substantial while the $\mathrm{K}$ content is quite low. In straw, the relationship is the opposite.

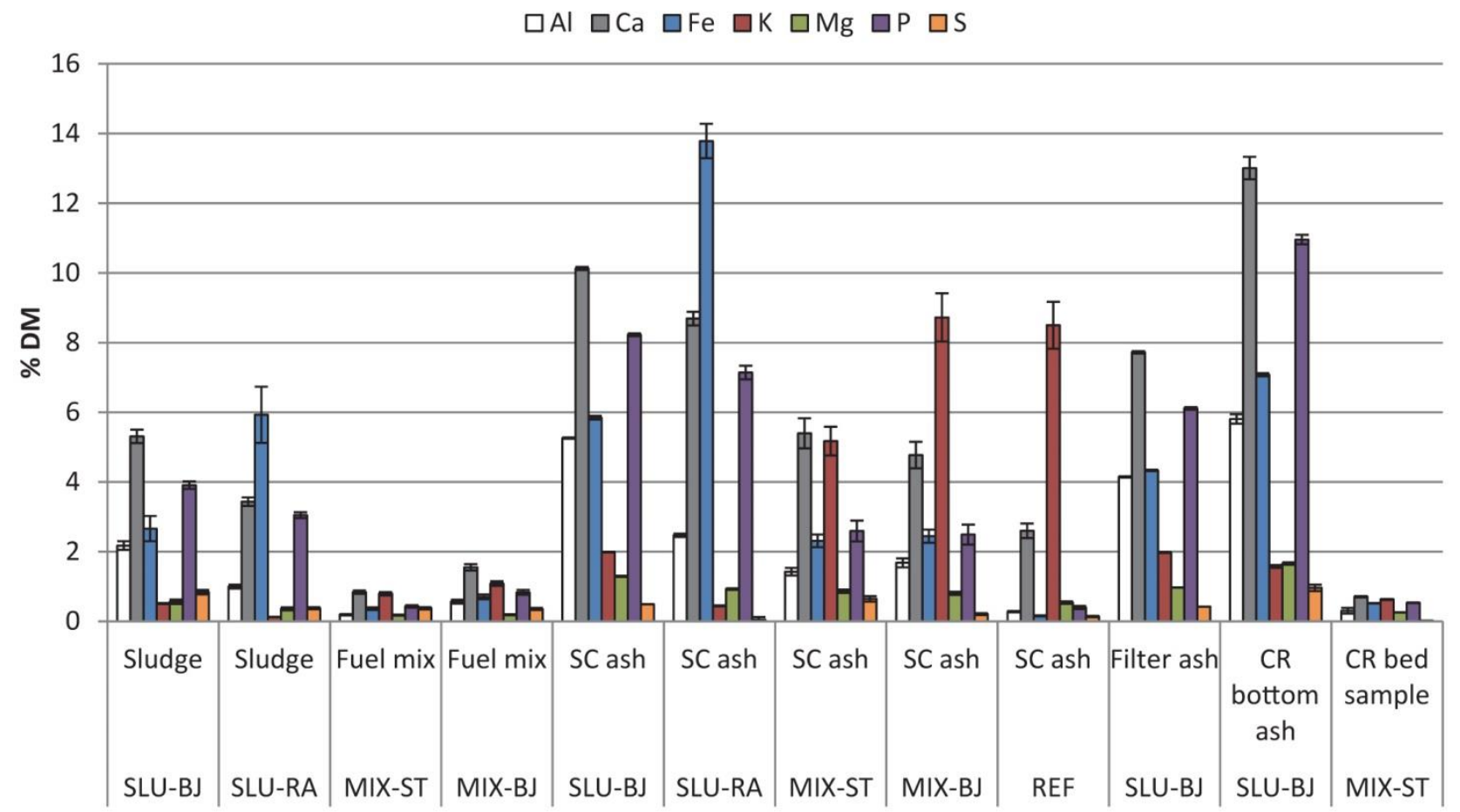

Figure 2: Content of selected elements in fuel and ash samples. Results given in \% of dry mass (\%DM). SC: Secondary cyclone. CR: Char reactor.

If including the content of recalcitrant carbon as a key characteristic of the ashes, the relationship between carbon, phosphorous and potassium can be expressed roughly as C:P:K = 1:1:0 (SLU-BJ \& SLU-RA), 10:1:2 (MIXST), 10:1:4 (MIX-BJ) and 110:1:21 (REF). The optimal P:K ratio will vary with soil, plant and climate, but the obtained results clearly indicate that it is possible to design the SC ash fertilizer in a very wide range of compositions depending on the MSS:straw ratio in the fuel. This is very important in regard to optimal utilization of $\mathrm{P}$ and $\mathrm{K}$ resources and economical value of the fertilizer ashes.

The content of aluminum ( $\mathrm{Al}$ ) and especially iron (Fe) has been found to have a profound negative influence on the plant $\mathrm{P}$ availability in sludge and deriving ashes (Krogstad et al., 2005; Pettersson et al., 2008). The ratio between $\mathrm{Al}$ and $\mathrm{Fe}$ in sludge was largely maintained in the ashes, and concentrations were increased with 100 $650 \%$ and $50-550 \%$ respectively.

Other elements such as magnesium (Mg), calcium (Ca) and sulfur ( $\mathrm{S}$ ) are also valuable plant nutrients contained in ashes (Nieminen et al., 2005). The content of $\mathrm{Ca}(1-13 \%)$ was found to be very high in ashes from monosludge campaigns. The concentrations of $\mathrm{Ca}$ and $\mathrm{Mg}$ in the ashes increased with $50-550 \%$ and $50-650 \%$ respectively while the concentrations of $S$ in the ashes were $15-170 \%$ of those in the corresponding fuel. 
However, plant availability of these elements in the ash products might vary, as shown in experiments by Nieminen et al (2005) using wood ash (Nieminen et al., 2005).

257

When applying sludge or ash as fertilizer or soil enhancer, the content of heavy metals is usually strongly regulated. In Denmark, heavy metals in sludge and ash are regulated either per unit of dry mass or per unit of total P mass. In the European Union, the regulation is per dry mass. Both set of results are included in Table 4.

Table 4: Contents of selected heavy metals in fuels and ashes. Results as mg heavy metal per kg dry matter (DM) and per kg total P. SC: Secondary cyclone. CR: Char reactor. BA: Bottom ash. BS: Bed sample. Grey marks a violation of the legal threshold for use of sludge and waste products in agricultural systems in Denmark (Danish Ministry of the Environment, 2008, 2006)

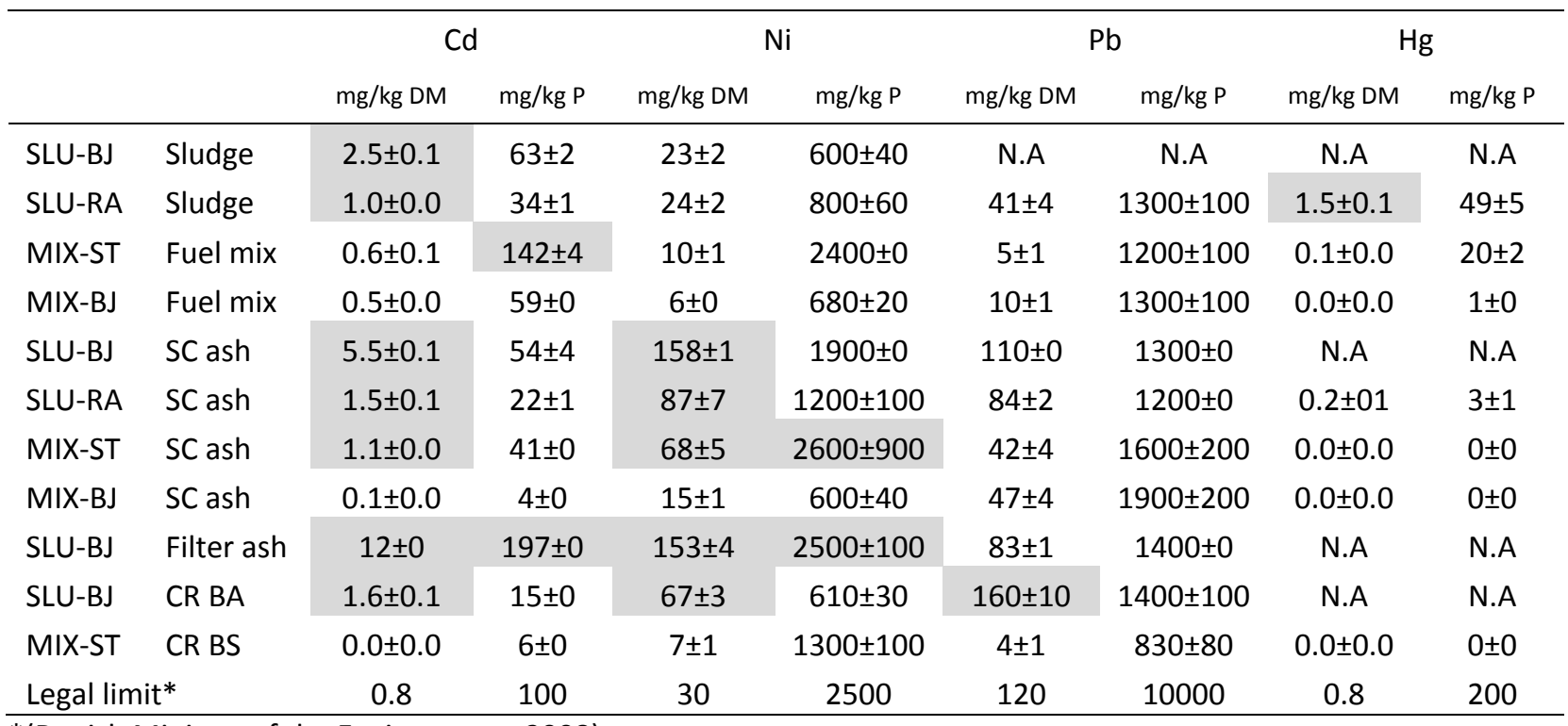

*(Danish Ministry of the Environment, 2008)

Legal thresholds per basis of dry mass were breached several times for contents of cadmium and nickel and a few times for lead and mercury. The thermal process concentrated thermally stable elements in the ashes as also observed in the assessment of major fertilizer elements (Figure 2), which is a severe drawback in regard to legal thresholds on basis of mass. With the regulation of heavy metals per unit of $P$, the pattern is different. For nickel and lead, the thermal gasification increased the concentration per unit of $P$, but the level of increase varied, and in a few cases the concentrations were even decreased. Ni content per unit of $\mathrm{P}$ increased substantially in all $100 \mathrm{~kW}$ campaigns (SLU-BJ, SLU-RA and MIX-ST). Little or no P is expected to be lost at the low temperatures, and the increase in the $\mathrm{Ni} / \mathrm{P}$ is expected to be due to leaching of $\mathrm{Ni}$ from the $\mathrm{CR}$ reactor steel lining as also observed in a study by Hernandez et al. (2011) (Hernandez et al., 2011). The pattern was not expressed in the $6 \mathrm{MW}$ campaign (MIX-BJ), and this is consistent with the hypothesis, as the $6 \mathrm{MW}$ CR reactor has inner refractory lining.

For cadmium and mercury there was a profound reduction per unit of $\mathrm{P}$ in all cyclone and bottom ash fractions collected. Mercury was almost completely removed in all ashes while the content of cadmium per unit of $P$ was reduced with $13-96 \%$. These findings are very important as mercury and cadmium are often considered the 
most problematic heavy metals when using MSS or ashes in agriculture (Roberts, 2014; Werther and Ogada, 1999). The cadmium content per unit of $P$ decreased significantly in SC ashes but much more in CR ashes. Furthermore, the reduction of Cd per unit P in SC ashes as well as in CR ashes compared to their parent fuels was a lot higher in MIX campaigns than in mono-sludge campaigns. During the thermal process, cadmium is evaporated out of the particulate matter and into the hot gas phase as a result of the temperatures in the pyrolysis and char reactors. Elemental cadmium melts at $321^{\circ} \mathrm{C}$ and has a fairly high vapor pressure around 50 kpa at $720^{\circ} \mathrm{C}$. Another relevant $\mathrm{Cd}$-species is cadmium chloride $\left(\mathrm{CdCl}_{2}\right)$, which melts around $568^{\circ} \mathrm{C}$ but has a vapor pressure generally a factor of 10 lower than elemental cadmium (Skudlarski et al., 1987; Stull, 1972). Some of the $\mathrm{Cd}$ liberated to the gas phase in the hot $\mathrm{CR}$ is probably re-condensed on the surface of particulate matter in the colder secondary cyclone. This explains the elevated $\mathrm{Cd}$-concentration in the $\mathrm{SC}$ ash compared to the $\mathrm{CR}$ ash. Through the secondary cyclone, the gas temperature drops to around $600^{\circ} \mathrm{C}$. At this temperature the vapor pressure of cadmium has decreased with almost a factor of 5 compared to the char reactor environment. As the gas cools further towards the filter, even more $\mathrm{Cd}$ is condensing out on entrained and captured particles. This explains the high Cd/P relationship in the SLU-BJ filter ashes, which was more than three times higher than in the fuel, 4 times higher than in the SC ash and 13 times higher than in the CR bottom ashes. Based on the high toxicity of $\mathrm{Cd}$, it is essential to keep the particle temperatures as high as possible in the separation processes following the gasification. If ash separation and handling is properly addressed, the LT-CFB sludge treatment can in this way be used to recover $P$ for use in agricultural systems where it would otherwise be banned. The hot gas candle filter applied in the SLU-BJ campaign was found to collect more than half of the released cadmium, and this could be an important aspect in relation to downstream treatment of product gas or boiler exhaust gas. Lowering the temperatures in the filter would most likely increase the $\mathrm{Cd}$ recovery in this part of the system.

301

Elemental system balances of the SLU-BJ and MIX-ST campaigns have been established for selected nutrients and heavy metals (Figure 3 and Figure 4).

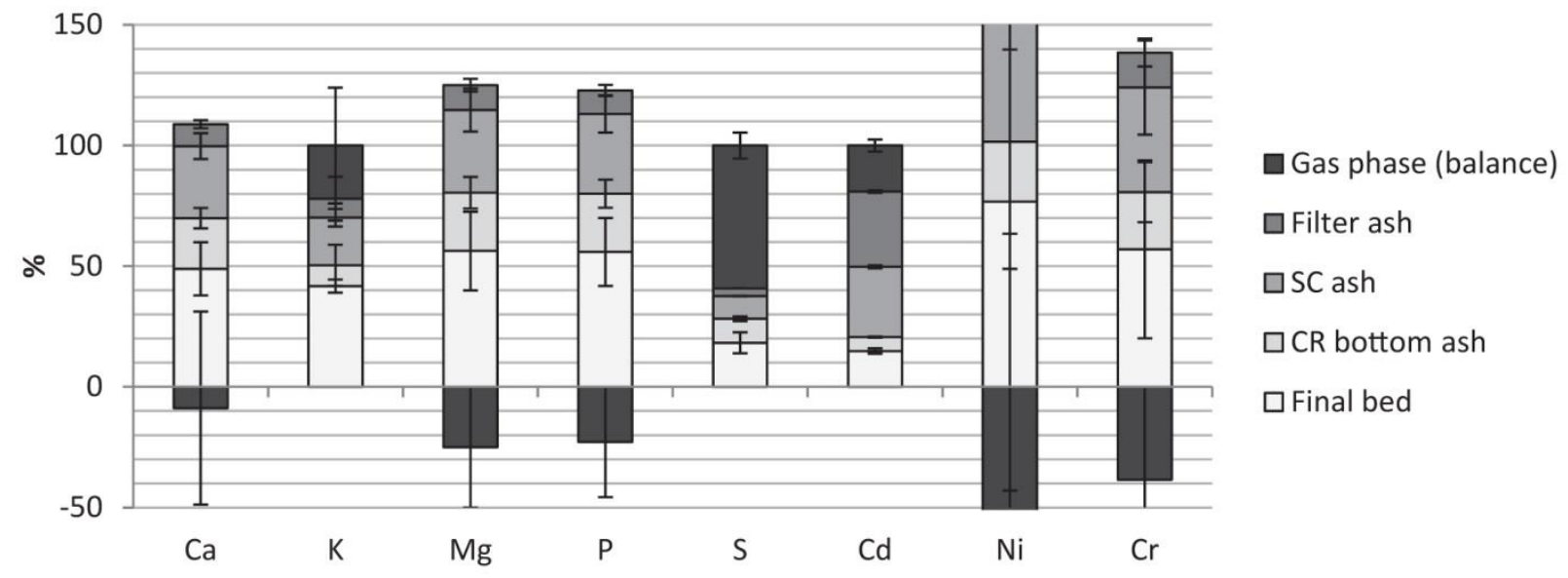

Figure 3: Elemental balance of SLU-BJ. Results given as element recovered in percent of element in fuel + virgin bed material 


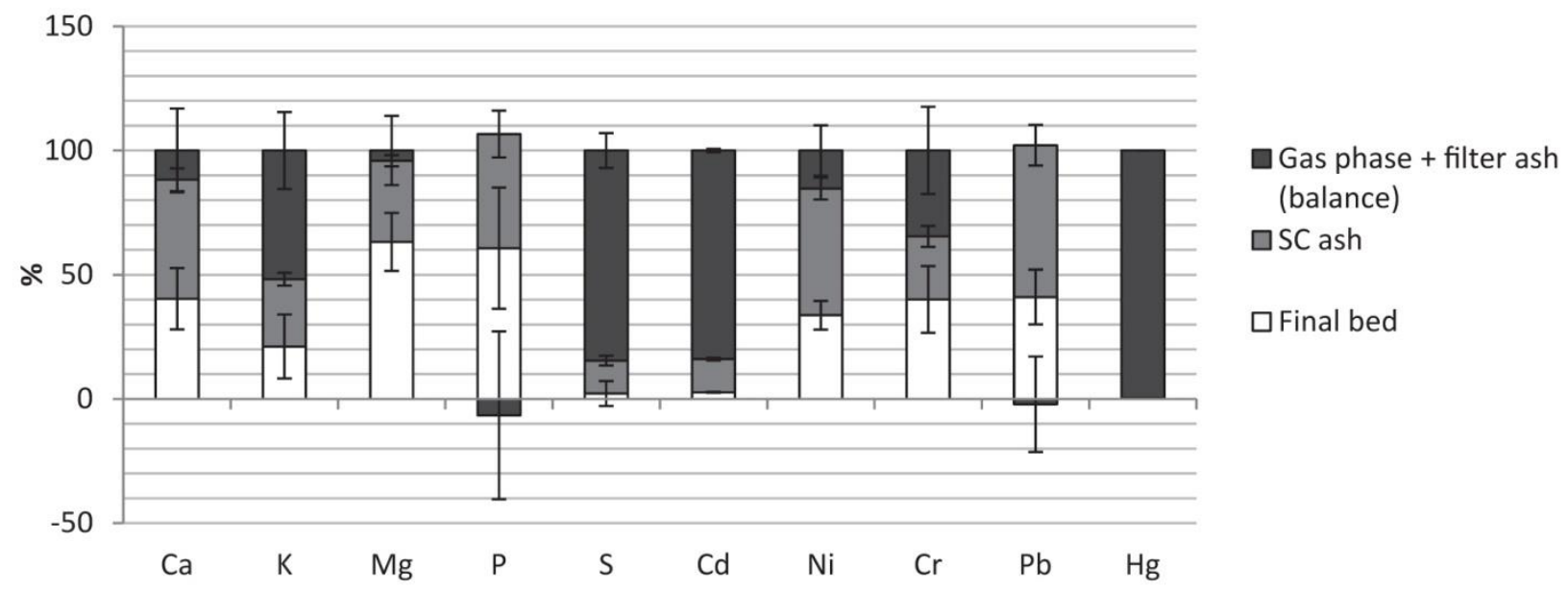

304

Figure 4: Elemental balance of MIX-ST. All results given as element recovered in percent of element in fuel + virgin bed material

The uncertainty related to the elemental mass balance is significant but a few strong trends can be derived. The substances $\mathrm{Mg}, \mathrm{P}, \mathrm{Ca}, \mathrm{K}$ and $\mathrm{Cr}$ were allocated quite consistently to the $\mathrm{SC}$ ash of both campaigns, but the distribution among the $\mathrm{CR}$ accumulation and gas phase was less consistent. In the SLU-BJ campaign the main inconsistency seems to relate to the $\mathrm{Ni}$ balance. The Ni-balance gap supports the theory previously presented regarding steel alloy leaching in the $100 \mathrm{~kW}$ campaigns. However, this is not supported by the MIX-ST results indicating that there is a big influence of the fuel and ash composition on the release of heavy metals. It is expected that the increase in total system $\mathrm{Cl}$ content by co-gasification with straw can facilitate additional release of heavy metals as also seen in $\mathrm{Cd}$ and $\mathrm{Cr}$ balances. This approach has been studied extensively as a MSS ash upgrading method (Adam et al., 2009; B Nowak et al., 2012; Benedikt Nowak et al., 2012; Vogel et al., 2011). The remaining results of the SLU-BJ campaign are in quite good agreement with the results from a series of tests conducted in a Circulating Fluidized Bed gasifier in Finland in the late 1990's (Kurkela, 2010).

\section{$3.3 \mathrm{pH}$}

The $\mathrm{pH}$ values of the sludge samples were close to 7 for all materials (Table 5). Gasification consistently increased $\mathrm{pH}$ compared to the respective sludge fuels to values between 10 and 11 .

Table 5: $\mathrm{pH}$ of sludge and ash samples in water. Maximum deviations between duplicates $<0.5 \%$. SC: Secondary cyclone. CR: Char reactor.

\begin{tabular}{lcccc}
\hline & Sludge & SC ash & Filter ash & CR Bottom ash \\
\hline SLU-BJ & 7.3 & 10.4 & 10.0 & 10.5 \\
SLU-RA & 6.8 & 11.1 & N.A. & N.A. \\
MIX-ST & 6.9 & 9.9 & N.A. & N.A. \\
MIX-BJ & 6.7 & 10.4 & N.A. & N.A. \\
REF & N.A. & 10.7 & N.A. & N.A. \\
\hline
\end{tabular}




\subsection{Ash P fertilizer quality assessment}

324

325

326

327

\subsubsection{Soil incubation study}

In the incubation study conducted, fuel mixes and straw fuels were not applied as they do not have practical relevance as pure $P$ fertilizers due to very low $P$ contents (Figure 2). The P concentration in the REF SC ash is also too low for use as pure $\mathrm{P}$ fertilizer, but it is included for interpretation of the mixed fuel ashes.

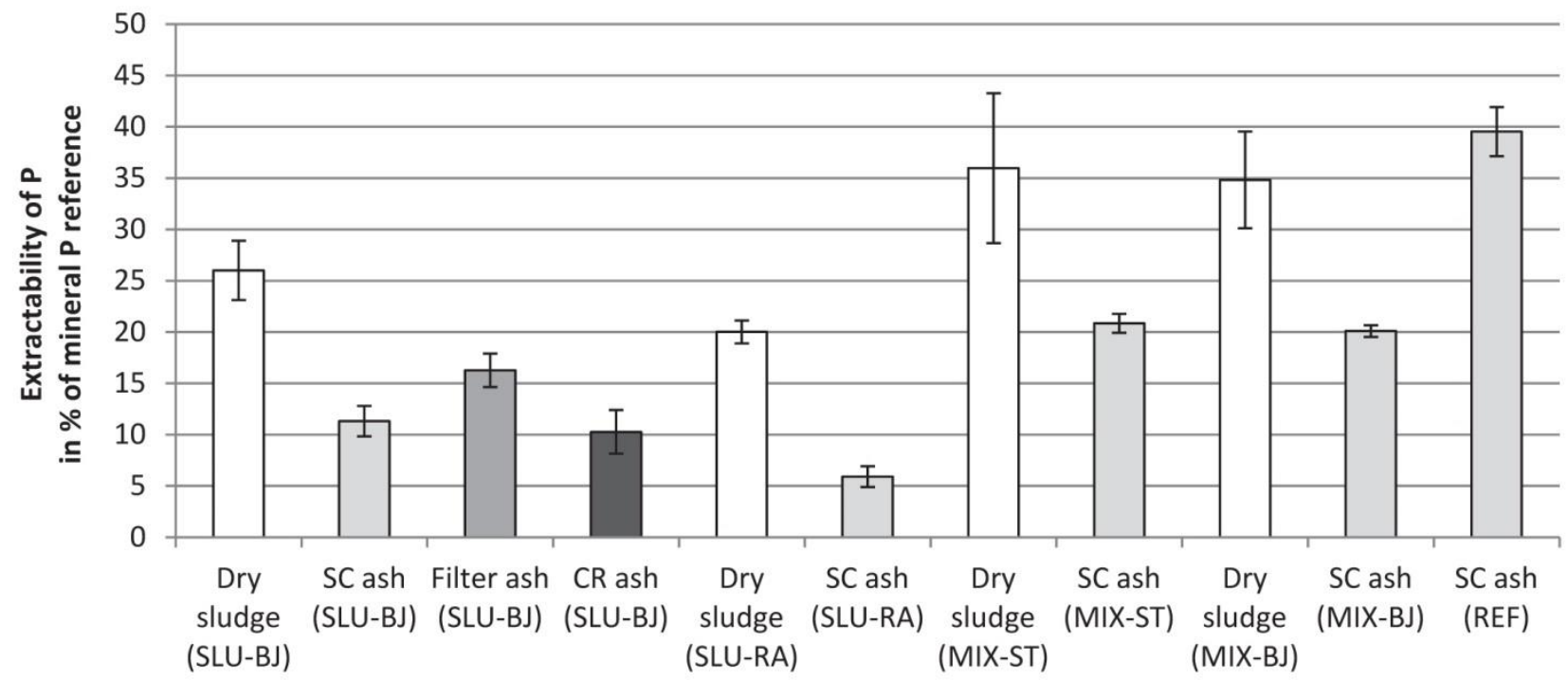

328

Figure 5: Water extractable $P$ in soil after the amendment with sludge and ash samples, relative to the mineral $P$ reference. Values of

the non-amended control soil have been subtracted. SC: Secondary cyclone. CR: Char reactor.

331 The screening results in Figure 5 show reduced plant $P$ availability in all incubated SC ashes compared to their parent sludge samples. The results also show that MIX ashes perform slightly better than all SLU ashes. In a previous study, co-pyrolysis of slaughterhouse waste with wood and corn residues have been found to lead to a beneficial modification in the P species and an increase in the P solubility and P fertilizer quality (Zwetsloot et al., 2015). It is therefore hypothesized that a similar effect could be part of the explanation behind the improved $\mathrm{P}$ availability of MIX ashes in the incubation study. However, with the current set of results, the influence from variations in the sludge composition cannot be distinguished from the influence of the cogasification with straw to an extent where it is actually possible to conclude if there is a significant improvement in the P quality. The mono-straw SC ash (REF) has a comparatively high plant available P pool, which makes it difficult to conclude on the optic of the potential improvements in the MSS P from gogasification. The good REF $P$ result could be due to the $P$ speciation alone but might as well be due to influence of other ash characteristics. As the P content of the REF SC ashes is very low, the dosage of REF SC ashes was a lot higher than for the other ashes - by weight as well as volume. Therefore, the potential effects on other soil parameters such as $\mathrm{pH}$ are expected to be higher for this ash than for the others. 
345 The MSS sample and SC ash from Randers WWTP (SLU-RA) performed worse than the comparable MSS and SC 346 ash samples. This may be expected from the fact that the dosing of Al and especially Fe-based precipitation

347 chemicals, which have the ability to form highly insoluble aluminum- and iron phosphates, is higher at Randers 348 compared to the other WWTPs (Parés Viader et al., 2015). However, despite the fact that the use of metal 349 based precipitation chemicals is higher at Bjergmarken WWTP than at Stegholt WWTP, no obvious difference 350 between MSS or ash samples from the two MIX-campaigns are obvious. Measured per unit of total $\mathrm{P}$, the $\mathrm{Al}$ 351 content in the sludge from Bjergmarken is almost a factor of 1.5 higher than the Al content in sludge from 352 Stegholt. The iron content on the other hand was almost identical in the two sludge samples and exactly the 353 same in the mixed samples. Assuming that the metal-based precipitation chemicals in general have a strong 354 influence on the P-solubility, these results could indicate that the iron content is a more important influence on 355 the $\mathrm{P}$ water solubility than the aluminum content. This is corroborated by a study of Pettersson et al. (2008), 356 who reported $\mathrm{P}$ extraction from sewage sludge ashes being more difficult when $\mathrm{P}$ had been precipitated with 357 Fe than with Al-based chemicals (Pettersson et al., 2008).

358 The SLU-BJ filter ash performed better than the SC ash and CR bottom ash from the same campaign in terms of $359 \quad P$ availability. From the data in Figure 2 the main differences in the elemental composition between the ash 360 fractions seem to be an increased content of alkali metals ( $\mathrm{Ca}$ and $\mathrm{K}$ ) per unit of $\mathrm{P}$ in the filter ash. This is also a 361 general trend in the MIX and REF ashes showing higher $\mathrm{P}$ availability compared to the SLU ashes. However, 362 despite the higher amount of available soil $\mathrm{P}$ after application of the filter ash compared to the SC ash and CR 363 ashes, the high relative content of heavy metals $\mathrm{Ni}, \mathrm{Cr}$ and especially $\mathrm{Cd}$ makes this ash unsuitable for 364 agricultural application. 
366 Without added $\mathrm{P}$, the growth of the barley plants was extremely restricted (only $2.9 \mathrm{~g}$ DM per pot,

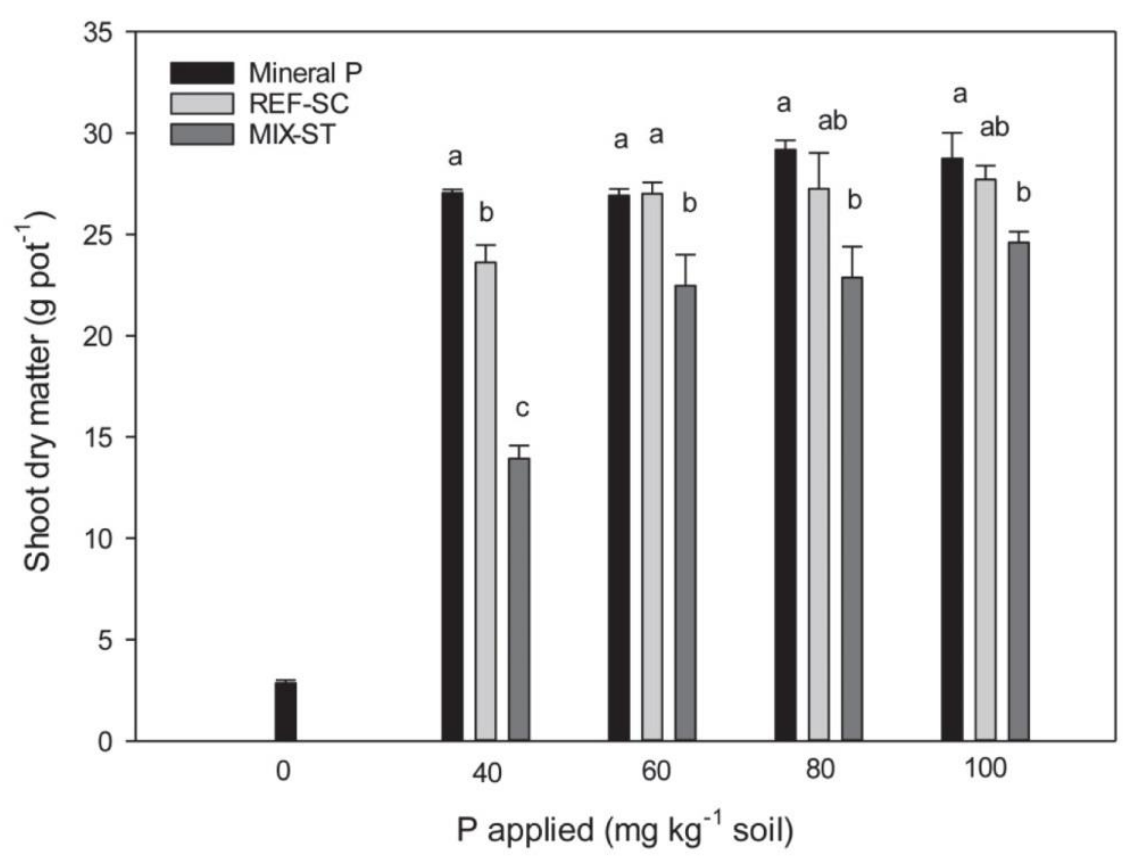

367

368 Figure 6) and the addition of mineral $P$ as well as ash greatly improved plant dry matter production already at $36940 \mathrm{mg} \mathrm{P} \mathrm{kg}^{-1}$ soil. As observed in previous experiments (Müller-Stöver et al., 2012), REF straw ash was very

370 effective in supplying $P$ to the plants, especially at higher application rates. Only at the lowest dosage applied, 371 REF ash application resulted in a significantly lower dry matter yield compared to mineral fertilizer, while at all 
372 other dosages, the same amount of plant dry matter as with mineral fertilizer could be produced with ash.

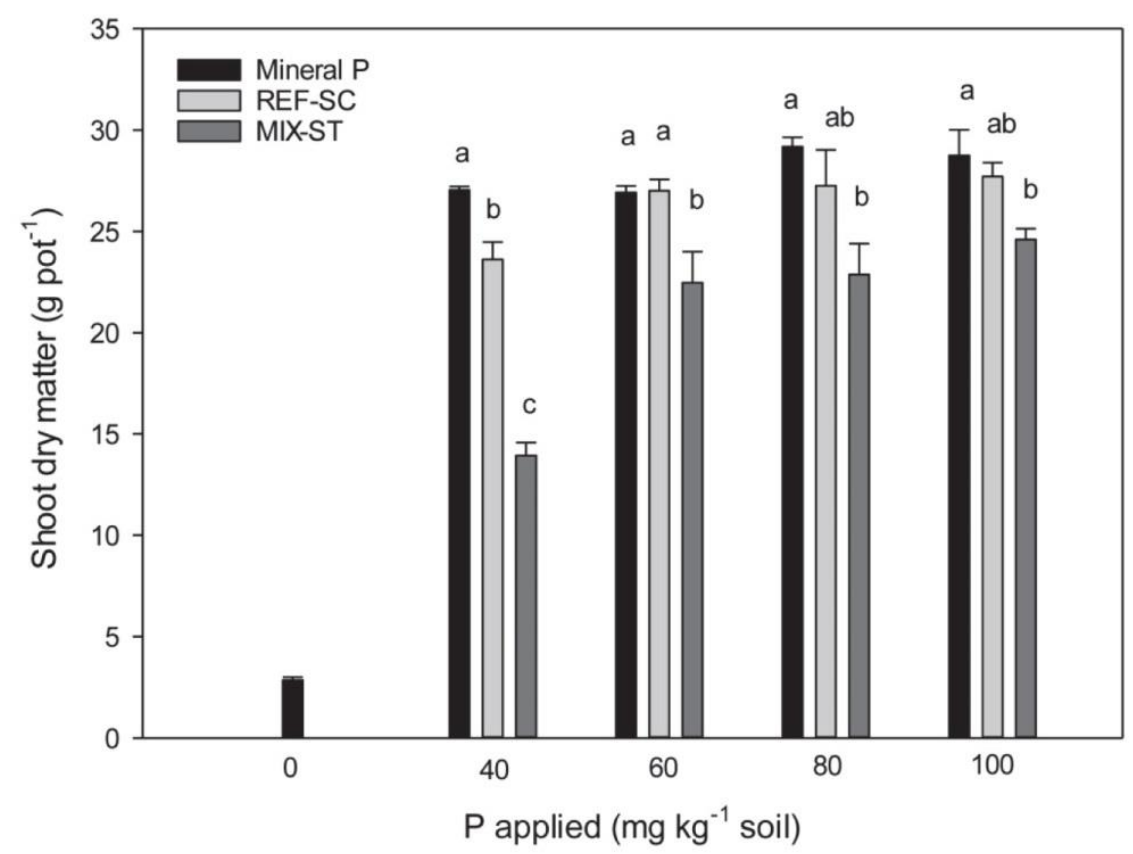

373 However, plant P uptake (

374 Figure 6) still showed the differences between $P$ availability in the two materials, indicating that $P$ uptake from

375 mineral $\mathrm{P}$ at the higher dosages was already beyond a level that still increases biomass production. In contrast,

376 the application of the MIX-ST ash - although also showing a strong positive dose-yield response and an

377 increasing relative effectiveness compared to mineral fertilizer- did never result in the same dry matter

378 production as the mineral fertilizer. However, $\mathrm{P}$ uptake was statistically similar at 60 and $80 \mathrm{mg} \mathrm{P} \mathrm{kg}^{-1}$ soil

379 between REF straw ash and MIX-ST ash, and no statistically significant difference in dry matter production 
could be observed between the two ash treatments at the two highest phosphorus levels (

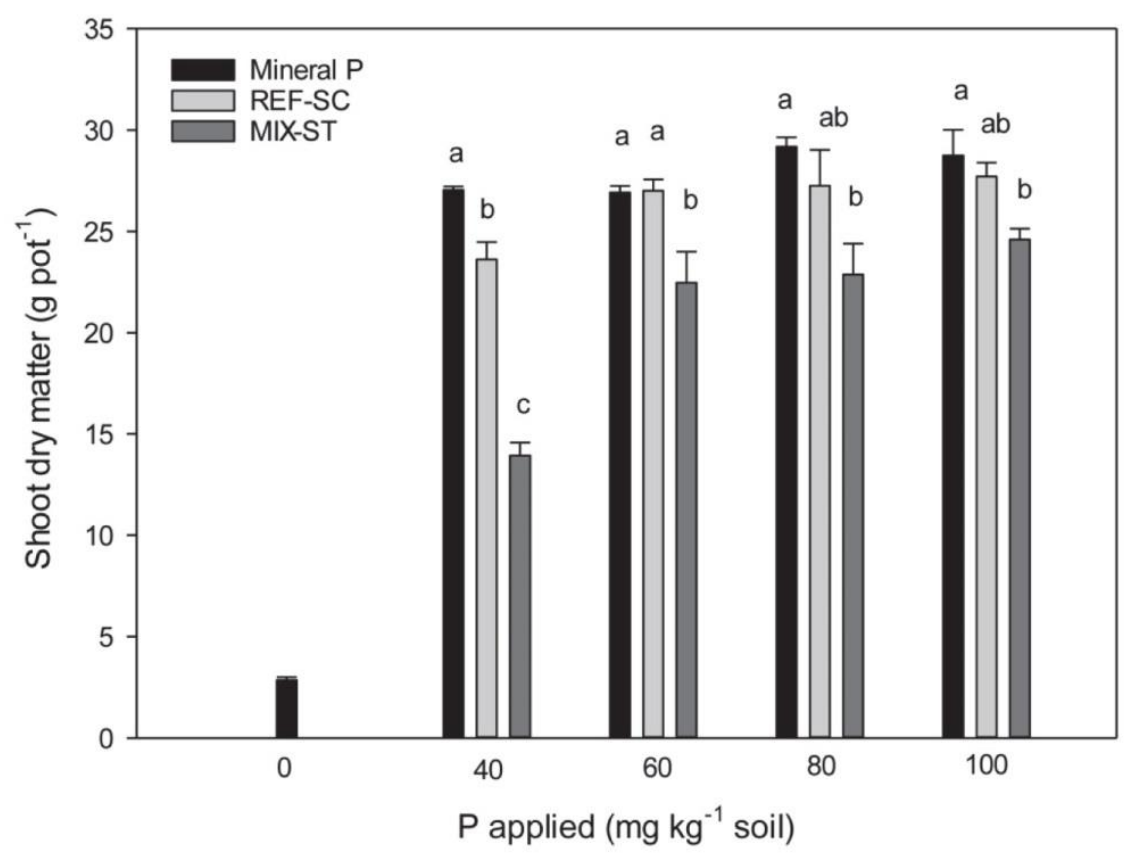

381

382 Figure 6 and Figure 7). P originating from both fuel components appeared plant-available in the MIX-ST ash, 383 since taking the fuel mixing ratio and the $\mathrm{P}$ content of the straw ash into consideration, at the highest application rate a maximum of $10 \mathrm{mg} \mathrm{P} \mathrm{kg}^{-1}$ soil could originate from the straw component in the mixed ash.

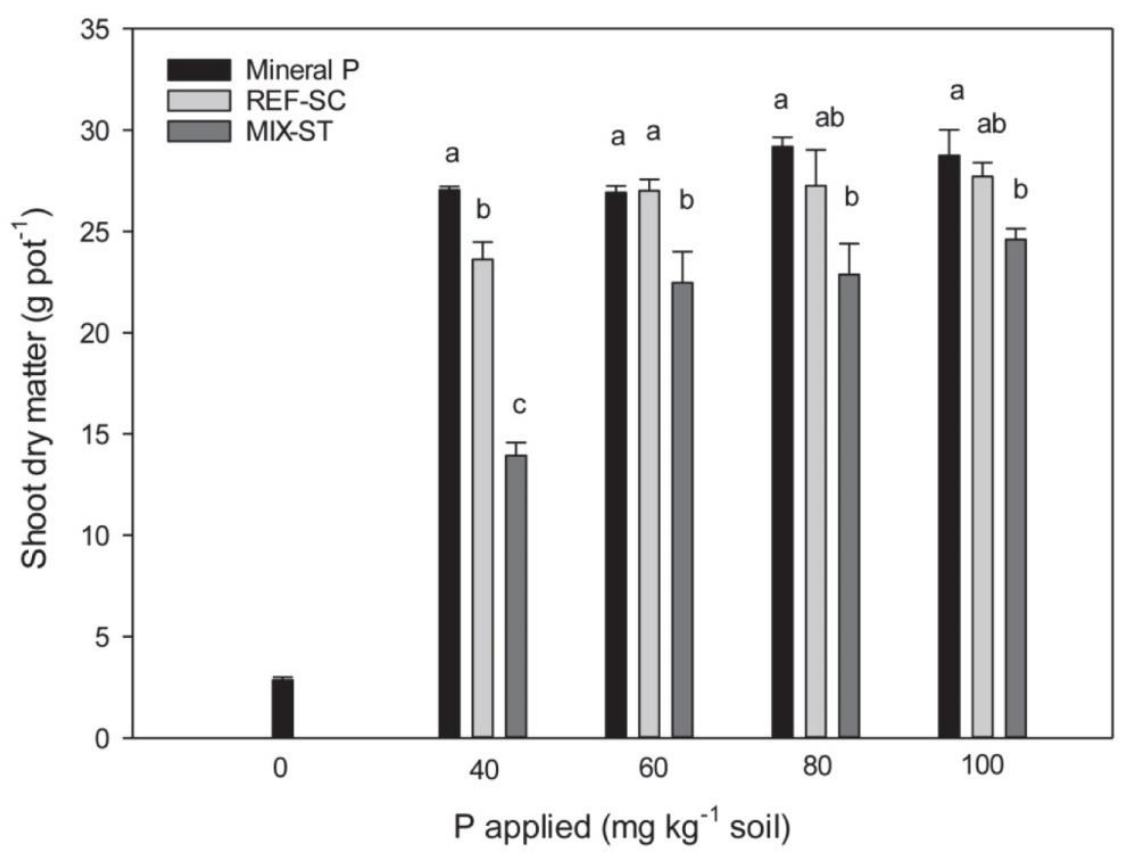




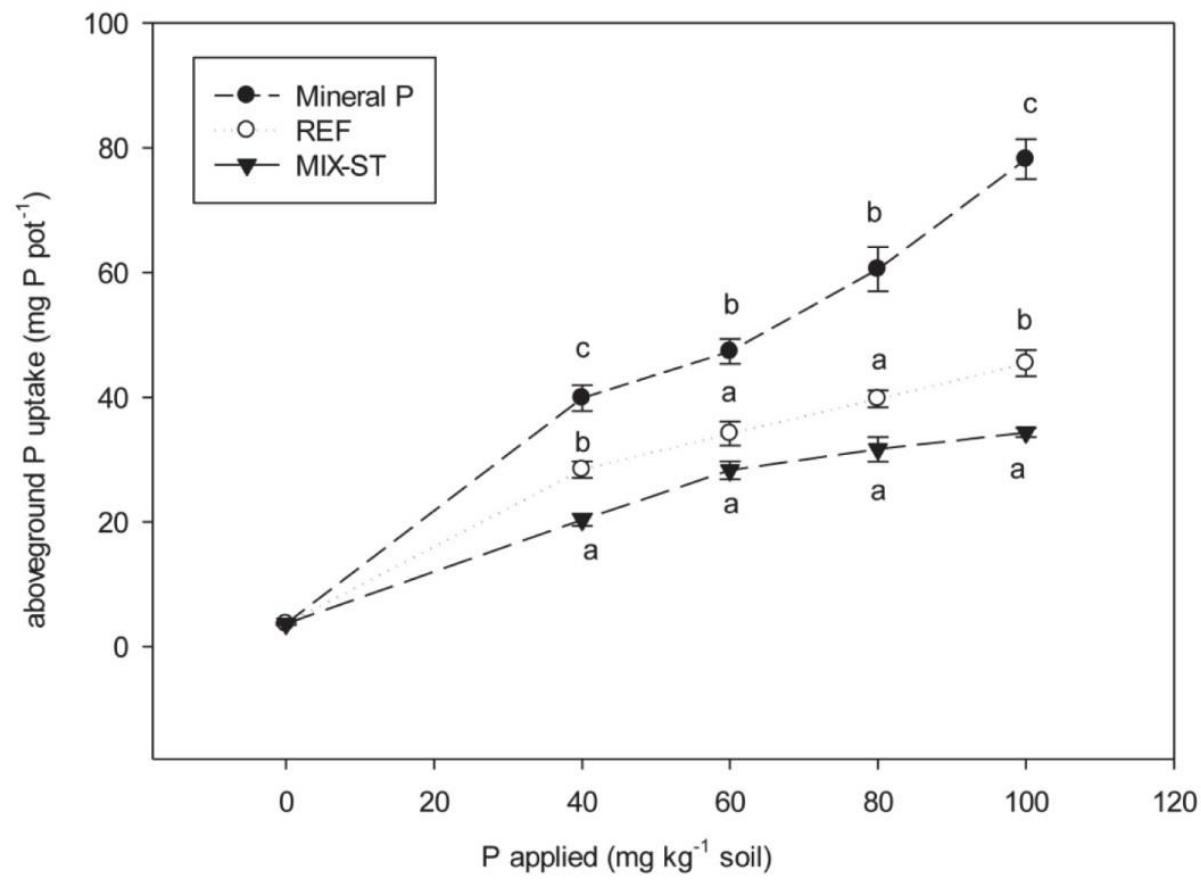

388

389

390

391

392

393

394

395

396

397

398

399

400

401

402

403

404

405

Figure 7: Plant phosphorus uptake in the treatments receiving mineral fertilizer or two different ash materials in various application rates. Different letters indicate statistically significant differences within the same application rate.

Qualitatively, the results of the pot experiment correspond quite well to those of the $\mathrm{P}$ screening. However, the performance of the REF and MIX-ST ashes relative to the mineral fertilizer was generally better in the pot experiment than in the simple screening. A weak correlation between water-extractable $P$ and plant $P$ uptake from more complex $P$ sources has been reported previously for rock phosphate (Bationo et al., 1991). Mackay et al. (1984) concluded that although water extraction might be useful to assess relative differences between fertilizer materials such as rock phosphates, it may be misleading when only relying on extraction methods to evaluate their agronomic effectiveness compared to more soluble P sources (Mackay et al., 1984).

\section{Conclusion}

Ash product fertilizer quality has been compared across five successful experimental LT-CFB campaigns with different fuels and plant scales. Four of the fuels were municipal sewage sludge or a mix of sludge and cereal straw. The fifth fuel was a reference straw fuel. Results have indicated that it is possible to modify desired characteristics of char and ash products from sludge gasification by co-gasification with straw in different ratios. If the sludge is dry, the mixing ratio can be from $0-100 \%$ sludge.

The $P$ fertilizer quality of ash and char samples was examined as water-extractable $P$ after soil amendment and in a plant pot experiment. Qualitatively, the results obtained after 1-week soil incubation corresponded to the 
results from the pot experiment. However, fertilizer efficiency of the ash samples had a tendency to be underestimated in the short-term assessment, revealing the need for more comprehensive soil-plant experimentation also including different soil types and plant species. Nevertheless, ashes from co-gasification of straw and sludge had higher plant $P$ availability than ashes from mono-sludge gasification, showing the potential to be developed into alternative P-fertilizer products.

Co-gasifying straw with sludge consistently increased ash fertilizer quality in regard to NPK composition, P plant availability and by a reduced content of heavy metals especially cadmium. In addition, co-gasification led to a higher content of recalcitrant carbon in the ashes increasing potential for beneficial biochar characteristics and long term carbon sequestration. Extracting ashes from the char reactor was found to yield ashes with an even lower content of heavy metals than the SC ashes, but the P fertilizer value was at the same time reduced. It was found that LT-CFB gasification of sludge was an effective way to purify and sanitize sewage sludge for subsequent use in agricultural systems, especially when co-gasifying sludge with cereal straw.

\section{Acknowledgements}

The authors deeply appreciate the technical and operational assistance obtained during the LT-CFB experiments and subsequent analytical work and would like to express a special appreciation to Zsuzsa Sárossy and Hanne Wojtaszewski from DTU KT, Lene Vigh and Lena Byrgesen from KU PLEN, Per L. Ambus from KU IGN and DONG Energy A/S. Finally the authors would like to thank the Danish Energy Authority for funding the work via the EUDP program.

\section{References}

Adam, C., Peplinski, B., Michaelis, M., Kley, G., Simon, F.G., 2009. Thermochemical treatment of sewage sludge ashes for phosphorus recovery. Waste Manag. 29, 1122-1128. doi:10.1016/j.wasman.2008.09.011

Ahrenfeldt, J., Thomsen, T.P., Henriksen, U., Clausen, L.R., 2013. Biomass gasification cogeneration - A review of state of the art technology and near future perspectives. Appl. Therm. Eng. 50, 1407-1417. doi:10.1016/j.applthermaleng.2011.12.040

Bationo, A., Baethgen, W., Christianson, C., Mokwunye, A., 1991. Comparison of five soil testing methods to establish phosphorus sufficiency levels in soil fertilized with water-soluble and sparingly soluble-P sources. Fertil. Res. 28, 271-279.

Choban, A., Winkler, I., 2008. Removal of highly toxic wastewater pollutants with excessive active sludge, in: Václavíková, M., Vitale, K., Gallios, G.P., Ivaničová, L. (Eds.), Water Treatment Technologies for the Removal of High-Toxicity Pollutants. Springer, Dordrecht, pp. 219-223.

Chowdhury, R.B., Moore, G.A., Weatherley, A.J., Arora, M., 2016. Key sustainability challenges for the global phosphorus resource, their implications for global food security, and options for mitigation. J. Clean. Prod. In Press, 1-19. doi:10.1016/j.jclepro.2016.07.012 
Cordell, D., White, S., 2014. Life's Bottleneck: Sustaining the World's Phosphorus for a Food Secure Future. Annu. Rev. Environ. Resour. Vol 39 39, 161-188. doi:DOI 10.1146/annurev-environ-010213-113300

Danish Ministry of the Environment, 2008. Bekendtgørelse om anvendelse af bioaske til jordbrugsformål (Eng.: Danish legislation on use of bio-ashes in agriculture). Copenhagen, Denmark.

Danish Ministry of the Environment, 2006. Bekendtgørelse om anvendelse af affald til jordbrugsformål (Eng.: Danish legislation on use of wastes in agriculture) [WWW Document]. BEK nr 1650, 13/12/2006. URL https://www.retsinformation.dk/forms/R0710.aspx?id=13056 (accessed 6.30.16).

ECN, 2016a. Phyllis2 - Database for biomass and waste [WWW Document]. URL https://www.ecn.nl/phyllis2/Browse/Standard/ECN-Phyllis\#sewage sludge (accessed 8.16.16).

ECN, 2016b. Phyllis2 - Database for biomass and waste [WWW Document]. URL https://www.ecn.nl/phyllis2/Browse/Standard/ECN-Phyllis\#wheat straw (accessed 8.16.16).

Edixhoven, J.D., Gupta, J., Savenije, H.H.G., 2013. Recent revisions of phosphate rock reserves and resources: reassuring or misleading? An in-depth literature review of global estimates of phosphate rock reserves and resources. Earth Syst. Dyn. Discuss. 4, 1005-1034. doi:10.5194/esdd-4-1005-2013

Fericelli, P.D., 2011. Comparison of sludge treatment by gasification vs. incineration, in: Ninth LACCEI Latin American and Caribbean Conference (LACCEI'2011). pp. 1-10.

Fraser, J.L., Lum, K.R., 1983. Availability of elements of environmental importance in incinerated sludge ash. Environ. Sci. Technol. 17, 52-54. doi:10.1021/es00107a013

Furr, A.K., Parkinson, T.F., Bache, C.A., Gutenmann, W.H., Pakkala, I.S., Lisk, D.J., 1980. Multielement Absorption by Crops Grown on Soils Amended with Municipal Sluge Ashes. J. Agric. Food Chem. 28, 660662.

Furr, a. K., Parkinson, T.F., Wachs, T., 1979. Multielement analysis of municipal sewage sludge ashes. Absorption of elements by cabbage grown in sludge ash-soil mixture. Environ. Sci. Technol. 13, 15031506. doi:10.1021/es60160a002

Fytili, D., Zabaniotou, A., 2008. Utilization of sewage sludge in EU application of old and new methods-A review. Renew. Sustain. Energy Rev. 12, 116-140. doi:10.1016/j.rser.2006.05.014

Hansen, T.H., Laursen, K.H., Persson, D.P., Pedas, P., Husted, S., Schjoerring, J.K., 2009. Micro-scaled highthroughput digestion of plant tissue samples for multi-elemental analysis. Plant Methods 5, 1-11.

Hansen, V., Hauggaard-Nielsen, H., Petersen, C.T., Mikkelsen, T.N., Müller-Stöver, D., 2016. Effects of gasification biochar on plant-available water capacity and plant growth in two contrasting soil types. Soil Tillage Res. 161, 1-9. doi:10.1016/j.still.2016.03.002

Hansen, V., Müller-Stöver, D., Ahrenfeldt, J., Kai Holm, J., Birk Henriksen, U., Hauggaard-nielsen, H., 2015. Gasification biochar as a valuable by-product for carbon sequestration and soil amendment. Biomass Bioeng. 72, 300-308. doi:http://dx.doi.org/10.1016/j.biombioe.2014.10.013

Hernandez, A.B., Ferrasse, J.H., Chaurand, P., Saveyn, H., Borschneck, D., Roche, N., 2011. Mineralogy and 
leachability of gasified sewage sludge solid residues. J. Hazard. Mater. 191, 219-227. doi:10.1016/j.jhazmat.2011.04.070

Hossain, M.K., Strezov, V., Nelson, P.F., 2015. Comparative Assessment of the Effect of Wastewater Sludge Biochar on Growth, Yield and Metal Bioaccumulation of Cherry Tomato. Pedosphere 25, 680-685. doi:10.1016/S1002-0160(15)30048-5

Hukari, S., Hermann, L., Nättorp, A., 2016. From wastewater to fertilisers - Technical overview and critical review of European legislation governing phosphorus recycling. Sci. Total Environ. 542, 1127-1135. doi:10.1016/j.scitotenv.2015.09.064

Igos, E., Benetto, E., Venditti, S., Kohler, C., Cornelissen, A., Moeller, R., Biwer, A., 2012. Is it better to remove pharmaceuticals in decentralized or conventional wastewater treatment plants? A life cycle assessment comparison. Sci. Total Environ. 438, 533-40. doi:10.1016/j.scitotenv.2012.08.096

Jakobsen, P., Willett, I.R., 1986. Comparisons of the fertilizing and liming properties of lime-treated sewage sludge with its incinerated ash. Fertil. Res. 9, 187-197. doi:10.1007/BF01050345

Kahiluoto, H., Kuisma, M., Ketoja, E., Salo, T., Heikkinen, J., 2015. Phosphorus in Manure and Sewage Sludge More Recyclable than in Soluble Inorganic Fertilizer. Environ. Sci. Technol. 49, 2115-2122. doi:10.1021/es503387y

Kelessidis, A., Stasinakis, A.S., 2012. Comparative study of the methods used for treatment and final disposal of sewage sludge in European countries. Waste Manag. 32, 1186-1195. doi:10.1016/j.wasman.2012.01.012

Krogstad, T., Sogn, T.A., Asdal, Å., Sæb $\varnothing$, A., 2005. Influence of chemically and biologically stabilized sewage sludge on plant-available phosphorous in soil. Ecol. Eng. 25, 51-60. doi:10.1016/j.ecoleng.2005.02.009

Krüger, O., Adam, C., 2015. Recovery potential of German sewage sludge ash. Waste Manag. Urban Mini, 400406. doi:10.1016/j.wasman.2015.01.025

Krüger, O., Grabner, A., Adam, C., 2014. Complete Survey of German Sewage Sludge Ash. Environ. Sci. Technol. 48, 11811-11818.

Kurkela, E., 2010. Thermal gasification for Power and Fuels [WWW Document]. VTT Tech. Res. Cent. Finl. URL http://www.vtt.fi/files/research/ene/bioenergy/gasification/thermal_gasification_for_power_and_fuels. pdf (accessed 5.27.16).

Li, R., Zhang, Z., Li, Y., Teng, W., Wang, W., Yang, T., 2015. Transformation of apatite phosphorus and nonapatite inorganic phosphorus during incineration of sewage sludge. Chemosphere 141, 57-61. doi:10.1016/j.chemosphere.2015.05.094

Linderholm, K., Tillman, A., Erik, J., 2012. Life cycle assessment of phosphorus alternatives for Swedish agriculture. Resour. Conserv. Recycl. 66, 27-39. doi:10.1016/j.resconrec.2012.04.006

Liu, T., Liu, B., Zhang, W., 2014. Short Communication: Nutrients and Heavy Metals in Biochar Produced by Sewage Sludge Pyrolysis: Its Application in Soil Amendment. Polish J. Environ. Stud. 23, 271-275.

Lu, H., Zhang, W., Wang, S., Zhuang, L., Yang, Y., Qiu, R., 2013. Characterization of sewage sludge-derived 
biochars from different feedstocks and pyrolysis temperatures. J. Anal. Appl. Pyrolysis 102, 137-143. doi:10.1016/j.jaap.2013.03.004

Mackay, A., Syers, J., Gregg, P., Tillman, R., 1984. A comparison of 3 soil-testing procedures for estimating the plant availability of phosphorus in soils receiving either superphosphate or phosphate rock. New Zeal. J. Agric. Res. 27, 231-245.

Manara, P., Zabaniotou, A., 2012. Towards sewage sludge based biofuels via thermochemical conversion - A review. Renew. Sustain. Energy Rev. 16, 2566-2582. doi:10.1016/j.rser.2012.01.074

Mellbye, M.E., Hemphill, D.D., Volk, V. V., 1982. Sweet corn growth on incinerated sewage sludge-amended soil. J. Environ. Qual. 11, 160-163.

Méndez, a., Gómez, a., Paz-Ferreiro, J., Gascó, G., 2012. Effects of sewage sludge biochar on plant metal availability after application to a Mediterranean soil. Chemosphere 89, 1354-1359. doi:10.1016/j.chemosphere.2012.05.092

Michael, I., Rizzo, L., McArdell, C.S., Manaia, C.M., Merlin, C., Schwartz, T., Dagot, C., Fatta-Kassinos, D., 2013. Urban wastewater treatment plants as hotspots for the release of antibiotics in the environment: a review. Water Res. 47, 957-95. doi:10.1016/j.watres.2012.11.027

Müller-Stöver, D., Ahrenfeldt, J., Holm, J.K., Shalatet, S.G.S., Henriksen, U., Hauggaard-Nielsen, H., 2012. Soil application of ash produced by low-temperature fluidized bed gasification: Effects on soil nutrient dynamics and crop response. Nutr. Cycl. Agroecosystems 94, 193-207. doi:10.1007/s10705-012-9533-x

Narayan, V., Jensen, P.A., Henriksen, U.B., Glarborg, P., Lin, W., Nielsen, R.G., 2016. Defluidization in fluidized bed gasifiers using high-alkali content fuels. Biomass Bioeng. 91, 160-174. doi:10.1016/j.biombioe.2016.05.009

Nguyen, T.L.T., Hermansen, J.E., Nielsen, R.G., 2013. Environmental assessment of gasification technology for biomass conversion to energy in comparison with other alternatives: the case of wheat straw. J. Clean. Prod. 53, 138-148. doi:10.1016/j.jclepro.2013.04.004

Nielsen, R.G., 2007. Optimering af Lav Temperatur Cirkulerende Fluid Bed forgasningsprocessen til biomasse med højt askeindhold (Eng.: Optimizing Low Temperature Circulating Fluidized Bed gasification for high alkali biomass). Technical University of Denmark, Lyngby, Denmark.

Nieminen, M., Piirainen, S., Moilanen, M., 2005. Release of mineral nutrients and heavy metals from wood and peat ash fertilizers: Field studies in Finnish forest soils. Scand. J. For. Res. 20, 146-153. doi:10.1080/02827580510008293

Nowak, B., Frías Rocha, S., Aschenbrenner, P., Rechberger, H., Winter, F., 2012. Heavy metal removal from MSW fly ash by means of chlorination and thermal treatment: Influence of the chloride type. Chem. Eng. J. 179, 178-185. doi:10.1016/j.cej.2011.10.077

Nowak, B., Wegerer, H., Aschenbrenner, P., Rechberger, H., Winter, F., 2012. Sewage sludge ash to phosphate fertilizer by chlorination and thermal treatment: residence time requirements for heavy metal removal. Environ. Technol. 33, 2375-2381. doi:10.1080/09593330.2012.669413 
Ott, C., Rechberger, H., 2012. The European phosphorus balance. Resour. Conserv. Recycl. 60, 159-172. doi:10.1016/j.resconrec.2011.12.007

Parés Viader, R., Jensen, P.E., Ottosen, L.M., Ahrenfeldt, J., Hauggaard-Nielsen, H., 2015. Electrodialytic extraction of phosphorus from ash of low-temperature gasification of sewage sludge. Electrochim. Acta In Press. doi:10.1016/j.electacta.2015.05.025

Pettersson, A., Åmand, L.E., Steenari, B.M., 2008. Leaching of ashes from co-combustion of sewage sludge and wood-Part II: The mobility of metals during phosphorus extraction. Biomass Bioeng. 32, 236-244. doi:10.1016/j.biombioe.2007.09.006

Qian, T., Jiang, H., 2014. Migration of Phosphorus in Sewage Sludge during Different Thermal Treatment Processes. Sustain. Chem. Eng. 2, 1411-1419.

Roberts, T.L., 2014. Cadmium and Phosphorous Fertilizers: The Issues and the Science. Procedia Eng. 83, 52-59. doi:http://dx.doi.org/10.1016/j.proeng.2014.09.012

Scholz, R.W., Wellmer, F., 2016. Comment on : "Recent revisions of phosphate rock reserves and resources : a critique" by Edixhoven et al . ( 2014 ) - clarifying comments and thoughts on key conceptions , conclusions and interpretation to allow for sustainable action. Earth Syst. Dyn. 7, 103-117. doi:10.5194/esd-7-103-2016

Scholz, R.W., Wellmer, F.W., 2013. Approaching a dynamic view on the availability of mineral resources: What we may learn from the case of phosphorus? Glob. Environ. Chang. 23, 11-27. doi:10.1016/j.gloenvcha.2012.10.013

Seggiani, M., Puccini, M., Raggio, G., Vitolo, S., 2012. Effect of sewage sludge content on gas quality and solid residues produced by cogasification in an updraft gasifier. Waste Manag. 32, 1826-1834. doi:10.1016/j.wasman.2012.04.018

Skudlarski, K., Dudek, J., Kapala, J., 1987. Thermodynamics of $\{\mathrm{xCdBr} 2+(1-\mathrm{x}) \mathrm{Cd} \mid 2\}(\mathrm{s})$ investigated by mass spectrometry. J. Chem. Thermodyn. 21, 785-788.

Song, X.D., Xue, X.Y., Chen, D.Z., He, P.J., Dai, X.H., 2014. Application of biochar from sewage sludge to plant cultivation: Influence of pyrolysis temperature and biochar-to-soil ratio on yield and heavy metal accumulation. Chemosphere 109, 213-220. doi:10.1016/j.chemosphere.2014.01.070

Sousa, A.A.T.C., Figueiredo, C.C., 2015. Sewage sludge biochar: effects on soil fertility and growth of radish. Biol. Agric. Hortic. 8765, 1-12. doi:10.1080/01448765.2015.1093545

Stull, D., 1972. American Institute of Physics Handbook, Third. ed. McGraw Hill, New York.

Thomsen, T.P., Ravenni, G., Holm, J.K., Ahrenfeldt, J., Hauggaard-Nielsen, H., Henriksen, U.B., 2015. Screening of various low-grade biomass materials for low temperature gasification: Method development and application. Biomass Bioeng. 79, 128-144. doi:10.1016/j.biombioe.2014.12.019

Thomsen, T.P., Sárossy, Z., Gøbel, B., Stoholm, P., Ahrenfeldt, J., Frandsen, F.J., Henriksen, U.B., 2016. Low Temperature Circulating Fluidized Bed gasification and co-gasification of Municipal Sewage Sludge. Part 1: Process performance and gas product. Waste Manag. Submitted. 
582 Vogel, C., Adam, C., Unger, M., 2011. Heavy metal removal from sewage sludge ash analyzed by 583 thermogravimetry. J. Therm. Anal. Calorim. 103, 243-248. doi:10.1007/s10973-010-0966-7

584 Wang, T., Camps Arbestain, M., Hedley, M., Bishop, P., 2012. Chemical and bioassay characterisation of $585 \quad$ nitrogen availability in biochar produced from dairy manure and biosolids. Org. Geochem. 51, 45-54. 586 doi:10.1016/j.orggeochem.2012.07.009

587 Werther, J., Ogada, T., 1999. Sewage sludge combustion. Prog. Energy Combust. Sci. 25, 55-116. 588 doi:10.1016/S0360-1285(98)00020-3

589 Zhu, J., Yao, Y., Lu, Q., Gao, M., Ouyang, Z., 2015. Experimental investigation of gasification and incineration characteristics of dried sewage sludge in a circulating fluidized bed. Fuel 150, 441-447. doi:10.1016/j.fuel.2015.02.031

Zwetsloot, M.J., Lehmann, J., Solomon, D., 2015. Recycling slaughterhouse waste into fertilizer: how do pyrolysis temperature and biomass additions affect phosphorus availability and chemistry? J. Sci. Food Agric. 95, 281-288. doi:10.1002/jsfa.6716 